\title{
The evaluation of the nutritional potential of five Mediterranean woody plants rich in phytocompounds
}

\author{
D. Aouadi ${ }^{1,2}$, L. Zorghi ${ }^{3}$, M. Neffati ${ }^{4}$ and H. Ben Salem ${ }^{5,6}$ \\ ${ }^{1}$ National Agricultural Research Institute of Tunisia (INRAT), Laboratory of Animal and Forage Productions, 2049 Ariana, Tunisia \\ 2 University of Carthage, Faculty of Sciences, Bizerte, 1054 Carthage, Tunisia \\ ${ }^{3}$ Research Unit of Macromolecular Biochemistry and Genetics, Faculty of Sciences, 2112 Gafsa, Tunisia \\ ${ }^{4}$ Arid Regions Institute (IRA), 4100 Medenine, Tunisia \\ ${ }^{5}$ Diversification and Sustainable Intensification of Production Systems Program, \\ International Center for Agricultural Research in the Dry Areas (ICARDA), 11195 Amman, Jordan
}

KEY WORDS: nutrients, phytocompounds, essential oils, gas production, woody plants

Received: 4 November 2013

Revised: 13 March 2015

Accepted: 15 June 2015

${ }^{6}$ Corresponding author:

e-mail: H.Bensalem@cgiar.org
ABSTRACT. The foliage of woody plants, Artemisia herba alba (ART), Eucalyptus globulus (EUC), Pistacia lentiscus (PIS), Rosmarinus officinalis (ROS) and Thymus capitatus (THY), growing in central Tunisia was analysed for contents of nutrients and phytocompounds, including essential oils (EOs) and tannins. PIS and THY were highest in neutral detergent fibre and condensed tannins, respectively. EUC had the highest levels of total phenols, total tannins and oxalates. The concentration of EOs was highest in ROS and THY (26.59 $\mathrm{ml} \cdot \mathrm{kg}^{-1}$ dry matter (DM) vs $14.14 \mathrm{ml} \cdot \mathrm{kg}^{-1}$ of DM, respectively). The EOs profiles differed among all the plant species. ROS and EUC EOs were composed mainly of 1,8 -cineole ( $27.86 \%$ and $50.19 \%$, respectively) while ART's EOs were dominated by camphor (16.28\%) and chrysanthenone (14.78\%). Carvacrol (44.24\%) was the chemotype of THY EOs. The major compound of PIS EOs was a-pinene (12.82\%). Biological assay showed that tannins affect the nutritive value of these plants. With the exception of THY, the association of polyethylene glycol to substrates incubated in calibrated syringes resulted in a major increase of gas production $(+21 \%$ to $+136 \%)$. Differences in the profiles of EOs extracted from the five woody species suggest that these EOs could differ in their impact on digestion and performance of ruminants.

\section{Introduction}

Shrubby vegetation is often the main feed resource for goats and sheep in dry areas. Nonetheless, successful integration of rangeland vegetation in livestock nutrition and the sustainable management of rangelands require appropriate characterization of the nutritive value of rangeland vegetation. Moreover, there is increasing interest in the use of natural compounds as alternative additives in ruminant feeding to improve the quality of meat and milk. Artemisia herba alba (ART), Eucalyptus globulus (EUC), Pistacia lentiscus (PIS), Rosmarinus officinalis (ROS) and Thymus capitatus (THY) are widespread in the Mediterranean area and used by the rural population for the extraction of essential oils (EOs), which represents an income-generating 
activity. These EOs, which are a volatile mixture of organic compounds obtained from plant material (flowers, seeds, leaves, fruits and roots) by physical means, are characterized by antibacterial, antiseptic and antioxidant properties (Derwich et al., 2011). In Tunisia, these medicinal and aromatic plants grow on native rangelands and most of them are browsed by sheep and goats. Extracts of these woody plants contain secondary compounds, such as EOs.

Recent studies on ruminants showed that EOs extracted from range species could be used as natural additives to manipulate rumen fermentation and to improve feed efficiency (Benchaar et al., 2007). However, to our knowledge there is a lack of information on the presence of secondary compounds and the profiles of EOs in a wide range of Mediterranean woody plants. Therefore, the purpose of our study on the foliage of five tree and shrub species growing in central Tunisia was to determine their nutrient contents, identify some secondary compounds, and characterize the EOs found in them.

\section{Material and methods}

\section{Plant material}

The foliage (leaves and flowers) of five woody plants called Artemisia herba alba (ART), Eucalyptus globulus (EUC), Pistacia lentiscus (PIS), Rosmarinus officinalis (ROS) and Thymus capitatus (THY) were harvested from native rangelands in Oueslatia (Central Tunisia, average annual rainfall $350 \mathrm{~mm}$ ) in the spring season (March and April 2009). The fresh material of each plant species was weighed then air-dried under shadow. Four samples from each species were dried at $50^{\circ} \mathrm{C}$, ground to pass through a $1 \mathrm{~mm}$ screen, and stored until analysed.

\section{Determination of nutrients}

The dry matter (DM) content of samples was determined by oven-drying at $100^{\circ} \mathrm{C}$ for $24 \mathrm{~h}$ (AOAC, 1984; method 967.03). Ash content was determined after $5 \mathrm{~h}$ incineration of the plant sample at $500^{\circ} \mathrm{C}$ in a muffle furnace (AOAC, 1990; method 942). Total $\mathrm{N}$ was determined by combustion analysis, and the crude protein (CP) concentration was calculated as $\mathrm{N} \times 6.25$ (AOAC, 1984; Kjeldhal-N, ID 7.015).

Total cell wall (neutral detergent fibre; Van Soest et al., 1991), lignocellulose and lignin (AOAC, 1990; acid detergent fibre) contents were determined using the sequential procedure of fibre fractionation. $\alpha$-amylase, but not sodium sulphite was used.

\section{Extraction of essential oils}

The air-dried foliage was subjected to 4-h steam distillation using the apparatus presented in the IX $^{\text {th }}$ edition of the French Pharmacopoeia, which is similar to the apparatus of Clavenger (Paris and Moyse, 1967). Yields of EOs are expressed as millilitre per kilogram of dry matter.

\section{Identification of components in EOs}

Total essential oil compounds were analysed according to Mighiri et al. (2010), using an Agilent $6890 \mathrm{~N}$ gas chromatograph (Agilent Technologies, Santa Clara, CA, USA) coupled to an Agilent 5973 B mass spectrometer (Agilent Technologies, Santa Clara, CA, USA). The percentage of each compound in the EOs was determined from the ratio between the peak area of the compound and the sum of areas of all peaks in the spectrum. The identification of compounds was based on the comparison of their mass spectra with those of pure compounds and those stored in databases of mass spectra of pure commercial products.

\section{Analysis of phytocompounds}

The procedures described by Makkar (2003) were adopted to analyse total extractable phenols (TP), tannins (TT) and condensed tannins (CT) in the ground samples of the five plant species. Duplicate samples of the foliage of each plant were tested.

Total extractable oxalates in the ground samples of the five plant species were analysed as described by Moir (1953).

\section{In vitro gas production}

The gas issued by incubation of each plant species with rumen inoculum was measured according to the procedure described by Menke and Steingass (1988). Triplicate samples of ground material of each plant species were incubated $(0.2 \mathrm{~g}$ of $\mathrm{DM})$ in calibrated glass syringes containing rumen fluid from three rumen-fistulated Barbarine rams and artificial saliva $(10 \mathrm{ml}$ and $20 \mathrm{ml}$, respectively) with or without 16.7 g polyethylene glycol (PEG 4000) per litre of inoculum. PEG was used to deactivate tannins leading normally to an increased digestion rate of the substrate. Therefore, the increase of gas production in syringes containing PEG would indicate that tannins are responsible for the low digestion of a substrate. The volume of gas produced in each syringe after $24 \mathrm{~h}$ incubation was recorded. Two runs were performed for each sample with each run containing three replicates per sample and three blanks. 


\section{Calculation and statistical analysis}

The metabolizable energy (ME) in the five plant species incubated in glass syringes was calculated using the equation of Menke and Steingass (1988):

$$
\begin{gathered}
\mathrm{ME}\left(\mathrm{MJ} \cdot \mathrm{kg}^{-1} \mathrm{DM}\right)=2.20+0.136 \mathrm{GP}+ \\
+0.0057 \mathrm{CP}+0.0002859 \mathrm{CP}^{2}
\end{gathered}
$$

where: $\mathrm{CP}$ - crude protein in $\mathrm{g} \cdot \mathrm{kg}^{-1} \mathrm{DM}, \mathrm{GP}$ - net gas production $(\mathrm{ml})$ from $200 \mathrm{mg}$ of substrate after $24 \mathrm{~h}$ of incubation.

Data on nutrient and antinutritive factors and gas production parameters were subjected to analysis of variance using the general linear model (GLM) procedure of SAS (1991). Differences between plant species were detected using Duncan's multiple range test.

\section{Results}

\section{Chemical composition and gas production}

Contents of nutrients and phytocompound factors in the foliage differed among the five plant species (Table 1). The CP content ranged from 7.61\% (EUC) to $11.46 \%$ (ART) of DM. NDF varied between $44.28 \%$ (ART) and $64.49 \%$ (TYM) of DM. THY had the highest in NDF and ADF content. Lignin amounts were relatively similar; ROS had the highest lignin content. All species contained secondary compounds, but at very different levels. ART and, to a lesser extent, PIS were relatively high in TP. PIS contained a high level of CT. EUC had a considerably higher concentrationin of total oxalates than that found in the other species $6.44 \%$ (EUC) vs $0.21 \%$ (ROS) of DM.

The volumes of total gas produced from the incubation of substrates with or without PEG are reported in Table 2. The incubation of THY
Table 2. Volumes of gas production after the incubation of substrates in absence or in presence of PEG 4000

\begin{tabular}{lllll}
\hline Species & GP (-PEG) & GP (+PEG) $\begin{array}{l}\text { Variation, } \\
\%\end{array}$ & $\begin{array}{l}\mathrm{ME}, \\
\mathrm{MJ} \cdot \mathrm{kg}^{-1} \mathrm{DM}\end{array}$ \\
\hline ART & $10.25^{\mathrm{b}}$ & $24.20^{\mathrm{a}}$ & 136.1 & $7.99^{\mathrm{a}}$ \\
EUC & $15.8^{\mathrm{c}}$ & $20.76^{\mathrm{ab}}$ & 31.4 & $6.44^{\mathrm{b}}$ \\
PIS & $12.73^{\mathrm{cb}}$ & $19.44^{\mathrm{b}}$ & 52.7 & $6.65^{\mathrm{b}}$ \\
ROS & $14.91^{\mathrm{c}}$ & $18.11^{\mathrm{b}}$ & 21.5 & $6.43^{\mathrm{b}}$ \\
THY & $23.56^{\mathrm{a}}$ & $18.41^{\mathrm{b}}$ & -21.8 & $7.51^{\mathrm{a}}$ \\
SEM & 3.90 & 9.08 & - & 0.156
\end{tabular}

$\mathrm{GP}$ - the net gas production, $\mathrm{PEG}$ - polyethylene glycol, ME - metabolizable energy; ART - Artemisia herba alba, EUC - Eucalyptus globulus, PIS - Pistacia lentiscus, ROS - Rosmarinus officinalis, THY - Thymus capitatus; a,b,c means with different superscipts within a column are significantly different at $P \leq 0.05$; SEM - standard error of the mean

generated the highest volume of gas, while the lowest gas production was recorded for ART. With the exception of THY, the provision of PEG to syringes containing the other plant species resulted in an increase of gas production, which was the highest for ART. The estimated ME in the foliage of the woody species ranged from 6.43 (ROS) to 7.99 (ART) MJ $\cdot \mathrm{kg}^{-1} \mathrm{DM}$.

\section{Essential oil yield and composition}

Yields of EOs extracted from the five plant species are given in Table 3. ROS and, to a lesser extent, THY gave the highest yields of EOs. The five plant species also exhibited different profiles of EOs (Table 3). Thirty-four components were identified in the EOs of ROS, with 1,8-cineole $(27.86 \%)$ and camphor $(12.71 \%)$ being the major components. Carvacrol (44.24\%) was the chemotype of THY EOs. EOs extracted from ART were dominated by camphor $(16.99 \%)$, chrysanthenone $(14.78 \%)$ and $\beta$-thujone (12.70\%).

\begin{tabular}{|c|c|c|c|c|c|c|c|c|c|}
\hline \multirow[b]{2}{*}{ Species } & \multirow{2}{*}{$\begin{array}{l}\text { Ash, } \\
\%\end{array}$} & \multirow{2}{*}{$\begin{array}{l}\text { Crude } \\
\text { protein, } \\
\%\end{array}$} & \multirow{2}{*}{$\begin{array}{l}\text { NDF, } \\
\%\end{array}$} & \multirow{2}{*}{$\begin{array}{l}\text { ADF, } \\
\%\end{array}$} & \multirow{2}{*}{$\begin{array}{l}\text { CT } \\
\text { g leucocyanidin, } \\
\mathrm{eq} \cdot \mathrm{kg}^{-1} \mathrm{DM}\end{array}$} & TT & TP & \multirow{2}{*}{$\begin{array}{l}\text { Oxalates, } \\
\mathrm{g} \cdot \mathrm{kg}^{-1} \mathrm{DM}\end{array}$} & \multirow{2}{*}{$\begin{array}{l}A D L \\
\%\end{array}$} \\
\hline & & & & & & \multicolumn{2}{|c|}{$\begin{array}{l}\mathrm{g} \text { tannic acid, } \\
\mathrm{eq} \cdot \mathrm{kg}^{-1} \mathrm{DM}\end{array}$} & & \\
\hline Artemisia herba alba & $4.84^{\mathrm{cd}}$ & $11.46^{\mathrm{a}}$ & $44.28^{c}$ & $29.41^{\mathrm{cb}}$ & $1.75^{\mathrm{c}}$ & nd & $14.20^{\mathrm{cd}}$ & $0.41^{\mathrm{c}}$ & $10.32^{\mathrm{a}}$ \\
\hline Eucalyptus globulus & $6.06^{\mathrm{a}}$ & $7.61^{\circ}$ & $49.05^{b}$ & $27.26^{d}$ & $2.81^{\mathrm{c}}$ & 14.4 & $31.20^{\mathrm{a}}$ & $6.44^{\mathrm{a}}$ & $8.15^{b}$ \\
\hline Pistacia lentiscus & $4.18^{d}$ & $8.80^{\mathrm{b}}$ & $52.02^{b}$ & $31.68^{c}$ & $32.15^{a}$ & nd & $20.81^{b}$ & $4.13^{b}$ & $9.72^{\mathrm{ab}}$ \\
\hline Rosmarinus officinalis & $5.29^{c b}$ & $7.82^{c}$ & $49.84^{b}$ & $35.43^{b}$ & $0.26^{b}$ & nd & $15.37^{c}$ & $0.21^{\mathrm{c}}$ & $11.20^{\mathrm{a}}$ \\
\hline Thymus capitatus & $5.75^{\mathrm{ab}}$ & $7.63^{c}$ & $64.49^{a}$ & $40.67^{a}$ & $2.10^{c}$ & nd & $10.85^{d}$ & $0.23^{c}$ & $9.57^{\mathrm{ab}}$ \\
\hline SEM & 0.23 & 0.11 & 9.22 & 5.94 & 0.76 & - & 6.05 & 0.19 & 1.41 \\
\hline
\end{tabular}

Table 1. Chemical composition of the foliage of woody plants

NDF - neutral detergent fibre, ADF - acid detergent fibre, CT - condensed tannins, TT - total tannins, TP - total phenols, ADL - acid detergent lignin; SEM - standard error of the mean; ${ }^{a-d}$ means with different superscipts within a column are significantly different at $P \leq 0.05$; nd - not detected 
Table 3. Main compounds of the essential oils extracted from the foliage of woody plants

\begin{tabular}{|c|c|c|c|c|c|c|c|c|c|c|c|c|}
\hline \multirow{2}{*}{\multicolumn{2}{|c|}{ Compound }} & \multicolumn{5}{|c|}{ Concentration, \% peak area } & \multirow{2}{*}{ Compound } & \multicolumn{5}{|c|}{ Concentration, \% peak area } \\
\hline & & ART & ROS & THY & EUC & PIS & & ART & ROS & THY & EUC & PIS \\
\hline 1. & Tricyclene & 1.83 & 0.30 & - & - & 0.92 & 42. Thymol & - & - & 0.65 & - & - \\
\hline 2. & a-Thujene & 0.22 & 1.10 & 2.02 & - & - & 43. Phenol & - & - & 0.26 & 1.84 & - \\
\hline 3. & a-Pinene & 2.28 & 9.10 & 2.94 & 10.42 & 12.82 & 44. Carvacrol & - & - & 44.24 & - & - \\
\hline 4. & Camphene & 5.35 & 5.27 & 0.41 & 0.30 & 2.88 & 45. a-Cubenene & - & 0.19 & - & - & 0.27 \\
\hline 5. & Verbenene & 0.81 & - & - & 0.17 & - & 46. 2- $\beta$-pinene & - & - & 0.97 & 0.20 & - \\
\hline 6 & Sabinene & 2.32 & - & 2.26 & - & 7.02 & 47. a-Ylangene & - & 0.15 & - & - & - \\
\hline 7. & $\beta$-Pinene & 0.82 & 8.44 & 0.33 & 0.38 & 5.57 & 48. a-Copaene & 1.57 & 0.62 & - & - & 1.48 \\
\hline 8. & 1-octen-3-ol & - & - & 0.37 & - & - & 49. Carvacryl acetate & - & - & 1.35 & - & - \\
\hline 9. & $\beta$-Phellandrene & 0.63 & - & - & - & 10.45 & 50. $\beta$-Elemene & - & - & - & - & 1.01 \\
\hline 10. & Myrcene & - & 2.32 & 2.45 & 0.21 & 4.33 & 51. Berbenone & 4.10 & - & - & - & - \\
\hline & a-Phellandrene & 0.27 & - & 0.63 & 0.56 & 10.13 & 52. Methyl eugenol & - & - & - & 0.24 & - \\
\hline & 1-Phellandrene & - & 0.48 & - & - & - & 53. $\beta$-Caryophyllene & 0.47 & 6.46 & 6.69 & 0.94 & 4.58 \\
\hline & $\delta$-3-Carene & - & 0.71 & 1.18 & 0.18 & - & 54. $\beta$-Cubebene & - & 0.34 & - & - & - \\
\hline & a-Terpinene & 0.37 & 1.38 & 2.74 & - & 1.59 & 55. Calarene & - & - & - & 0.31 & - \\
\hline 15. & p-Cymene & 1.77 & - & 8.71 & - & 2.16 & 56. Alloaromadendrene & - & 0.12 & 0.22 & 5.4 & - \\
\hline 16. & 1,8-Cineole & 7.88 & 27.86 & - & 50.19 & - & 57. a-Humulene & - & 0.88 & - & - & 1.27 \\
\hline 17. & a-pipene & - & - & - & - & 0.53 & 58. 4,7,10-Cycloundecatriene & - & - & 0.45 & - & - \\
\hline 18. & Trans- $\beta$-Ocimene & - & 0.80 & - & - & 0.78 & 59. Neoalloocimene & - & - & - & - & 0.61 \\
\hline 19. & y-Terpinene & 0.52 & 2.40 & 8.66 & 0.49 & 2.33 & 60. $\Delta$-Cadinene & - & - & 1.08 & - & - \\
\hline 20. & $\beta$-sabinene hydrate & - & 0.42 & - & - & - & 61. a-amorphene & - & 0.58 & 0.12 & - & - \\
\hline 21. & Terpinolene & 0.83 & 1.28 & 2.47 & - & 1.70 & 62. Naphthalene & - & - & - & - & 2.06 \\
\hline & Linalool & - & 1.20 & 2.30 & - & - & 63. Germacrene & 2.00 & - & 0.89 & - & 6.86 \\
\hline & $\beta$-Thujone & 12.70 & - & - & - & - & 64. $\beta$-cubebene & - & - & 0.16 & - & - \\
\hline 24. & Fenchol & - & - & - & 0.32 & - & 65. $\beta$-selinene & - & - & - & 0.19 & - \\
\hline 25. & a-Thujone & 8.42 & - & - & - & - & 66. a-selinene & - & 0.20 & - & - & - \\
\hline & $\begin{array}{l}\text { a-Campholene } \\
\text { aldehyde }\end{array}$ & - & - & - & 0.40 & - & 67. bicyclogermacrene & 0.73 & - & - & - & - \\
\hline & Chrysanthenone & 14.78 & - & - & - & 0.24 & 68. a-Muurolene & - & 0.16 & - & - & 1.87 \\
\hline & Isopinocarveol & - & - & - & 9.75 & - & 69. Caryophyllene & - & 0.19 & - & - & - \\
\hline 29. & Camphor & 16.99 & 12.71 & - & - & 0.55 & 70. a-amorphene & - & 0.25 & - & - & 0.76 \\
\hline 30 & Pinocarvone & 2.64 & - & - & - & - & 71. $\delta$-Cadinene & - & 0.70 & 0.14 & 0.27 & 3.55 \\
\hline & Borneol & 2.61 & 4.98 & 1.16 & 0.80 & - & 72. Epiglobulol & - & - & - & 0.38 & - \\
\hline & 4-terpinol & - & 1.91 & 0.91 & - & 1.24 & 73. Spathulenol & - & - & 0.15 & - & - \\
\hline & Terpinen-4-ol & 1.41 & - & - & 0.25 & - & 74. $\beta$-Bisabolene & - & 0.25 & 0.11 & - & - \\
\hline & a-Terpineol & 0.38 & 0.93 & - & 0.60 & 0.20 & 75. Levomenol & - & - & 0.92 & - & - \\
\hline & Myrtenal & 0.43 & - & - & 0.25 & - & 76. Viridiflorol & - & - & - & 2.29 & - \\
\hline & Verbenone & 0.46 & - & - & 0.18 & - & 77. Phenanthrene & - & - & 0.20 & 0.18 & - \\
\hline & Trans carveol & - & - & - & 0.18 & - & 78. Neophytadiene & - & - & - & - & 3.87 \\
\hline & Benzaldehyde & 0.49 & - & - & - & - & $\begin{array}{l}\text { 79. 1,2-benzenedicarboxylic } \\
\text { acid }\end{array}$ & - & - & 0.79 & 4.06 & 0.21 \\
\hline & $\begin{array}{l}\text { Chrysanthenyl } \\
\text { acetate }\end{array}$ & 1.90 & - & - & - & - & 80. Total compounds, $\%$ & 99.91 & 97.66 & 98.95 & 91.98 & 97.12 \\
\hline & Bornylacetate & 1.93 & 2.98 & - & - & 2.13 & 81. Yield, $\mathrm{ml} \cdot \mathrm{kg}^{-1} \mathrm{DM}$ & 2.30 & 26.59 & 14.14 & 3.00 & 1.10 \\
\hline & 2-Undecanone & - & - & - & - & 1.15 & & & & & & \\
\hline
\end{tabular}

ART - Artemisia herba alba, EUC - Eucalyptus globulus, PIS - Pistacia lentiscus, ROS - Rosmarinus officinalis, THY - Thymus capitatus;

\section{Discussion}

A wealth of information on the nutrient contents of woody species foliage is reported in the literature (Ben Salem et al., 1994). Addition of PEG increased gas production in syringes contain- ing CT-rich species. This suggests that in this case, tannins are responsible for the low nutritive value of these plant species (Makkar, 2003). Overall, the current work showed great variation among the five plant species evaluated in terms of the content of several nutrients (NDF, ADF, ADL and $\mathrm{CP}$ ) and 
phytocompounds (oxalates, TP and CT) and also of biological parameters (i.e. GP and ME). There are many factors that could explain this variation, including environmental conditions, season and stage of maturity. All of the plant species used in this study had oxalate contents lower than the threshold $\left(20 \mathrm{~g} \cdot \mathrm{kg}^{-1} \mathrm{DM}\right)$ considered by McKenzie et al. (1988) as harmful to animals.

The yields of EOs from the five plant species are in the range $(1.3 \%-3.0 \%$ of DM) of those reported in the literature, particularly for ROS growing in Morocco (Derwich, 2011) and in some woody species $(2.95 \%)$ growing in southeastern Tunisia (Akrout, 2004). Similarly to our results, Bounatirou et al. (2007) found that the main component of THY EOs is carvacrol $(73 \%)$, with high levels of $p$-cymene $(5 \%-17 \%)$ and $\gamma$-terpinene $(2 \%-14 \%)$. The composition of EOs from EUC and ROS found in this study is in line with previous studies (AitOuazzou et al., 2011) showing monoterpenes as the predominant components and 1,8-cineole, which is known for its strong antimicrobial properties against many important pathogens, as the major compound in both EOs (Rosato et al., 2007). Zaouali and Boussaid (2008) studied the variations in EOs extracted from local populations of ROS growing in Tunisia. They noted that the EOs extracted from populations growing in the sub-humid and upper semi-arid regions of Tunisia (Cap Bon and Tunisian Dorsal) were high in 1,8-cineole, while those from plants collected in the Matmata region (southern Tunisia, arid climate) were high in camphor. In addition to region and climate effects, Carvalho et al. (2005) claimed that the composition of EOs depended on the extraction technique. However, the variation in EOs profiles would be induced by the presence of chemotypes (Zrira et al., 2003).

The EOs of foliage of PIS are composed mainly of $\alpha$-pinene $(12.82 \%)$, $\alpha$-phellandrene $(10.12 \%)$ and $\beta$-phellandrene (10.45\%). PIS growing in Egypt was characterized by $\Delta$-3-carene, $\beta$-bisabolene and $\beta$-bourbonene (Zrira et al., 2003). Camphor is the major component in ART EOs. Cineole was reported as the major component in the EOs in ART growing in Spain, Egypt and Morocco. The oil extracted from ART growing in Tunisia has a very low concentration of 1,8-cineole (Neffati et al., 2008), confirming previous studies performed on the oil of the same shrub species growing in Algeria and Jordan (Hudaib and Aburjai, 2006). In the current study, chrysanthenone was found at high concentrations (14.78\%) in ART. In Spain and Algeria, chrysanthenone was present in amounts comparable to those found in this study (Dob and Benabdelkader, 2006).
Environmental factors such as location, temperature and day length considerably affect the chemical composition of EOs (Scora, 1973). These factors influence the plant's biosynthetic pathways and, consequently, the relative proportion of the main compounds.

\section{Conclusions}

This study provides new information on the composition of essential oils (EOs) extracted from aromatic plants growing in a semi-arid region of Tunisia. The five woody species exhibited different profiles of EOs, suggesting that animals would respond differently to these plants.

\section{References}

Ait-Ouazzou A., Loran S., Bakkali M., Laglaoui A., Rota C., Herrera A., Pagan R., Conchello P., 2011. Chemical composition and antimicrobial activity of essential oils of Thymus algeriensis, Eucalyptus globulus and Rosmarinus officinalis from Morocco. J. Sci. Food Agric. 91, 2643-2651

Akrout A., 2004. Study of essential oils of some pastoral plants on the area of Matmata. Cah. Options Médit. 62, 289-292

AOAC, 1984. Association of Officinal Analytical Chemists, Official Methods of Analysis. $14^{\text {th }}$ Edition. Washington, DC

AOAC, 1990. Association of Official Analytical Chemists, Official Methods of Analysis. $15^{\text {th }}$ Edition. Arlington, VA

Benchaar C., Petit H.V., Berthiaume R., Ouellet D.R., Chiquette J., Chouinard P.Y., 2007. Effects of essential oils on digestion, ruminal fermentation, rumen microbial populations, milk production, and milk composition in dairy cows fed alfalfa silage or corn silage. J. Dairy Sci. 90, 886-897

Ben Salem H., Nefzaoui A., Abdouli H., 1994. Palatability of shrubs and fodder trees measured on sheep and dromedaries. 1-Methodological approach. Anim. Feed Sci. Tech. 46, 143-153

Bounatirou S., Smiti S., Miguel M.G., Faleiro L., Rejeb M.N., Neffati M., Costa M.M., Figueiredo A.C., Barroso J.G., Pedro L.G., 2007. Chemical composition, antioxidant and antibacterial activities of the essential oils isolated from Tunisian Thymus capitatus Hoff. Et Link. Food Chem. 105, 146-155

Carvalho Jr. R.N., Moura L.S., Rosa P.T.V., Meireles M.A.A., 2005. Supercritical fluid extraction from rosemary (Rosmarinus officinalis): Kinetic data, extract's global yield, composition, and antioxidant activity. J. Supercrit. Fluids 35, 197-204

Derwich E., Benziane Z., Chabir R., Taouil R., 2011. In vitro antibacterial activity and GC/MS analysis of the essential oil extract of leaves of Rosmarinus officinalis grown in Morocco. Int. J. Pharm. Pharm. Sci. 3, 89-95

Dob T., Benabdelkader T., 2006. Chemical composition of the essential oil of Artemisia herba-alba Asso grown in Algeria. J. Essent. Oil Res. 18, 685-690

Hudaib M., Aburjai T., 2006. Composition of the essential oil from Artemisia herba-alba grown in Jordan. J. Essent. Oil Res. 18, 301-304

Makkar H.P.S. (Editor), 2003. Quantification of Tannins in Tree and Shrub Foliage. A Laboratory Manual. Kluwer Academic Publishers. Dordrecht (The Netherlands), pp. 102

McKenzie R.A., Bell A.M., Storie G.J., Keenan F.J., Cornack K.M., Grant S.G., 1988. Acute oxalate poisoning of sheep by buffel grass (Cenchrus ciliaris). Aust. Vet. J. 65, 26

Menke K., Steingass H., 1988. Estimation of the energetic feed value from chemical analysis and in vitro gas production using rumen fluid. Anim. Res. Dev. 28, 7-55 
Mighiri H., Hajlaoui H., Akrout A., Najjaa H., Neffati M., 2010. Antimicrobial and antioxidant activities of Artemisia herbaalba essential oil cultivated in Tunisian arid zone. C. R. Chimie 13, 380-386

Moir K.W., 1953. The determination of oxalic acid in plants. Queensland J. Agr. Sci. 10, 1-3

Neffati A., Skandrani I., Sghaier M.B., Bouhlel I., Kilani S., Ghedira K., Neffati M., Cherif I., Hammami M., Chekir-Ghedira L., 2008. Chemical composition, mutagenic and antimutagenic activities of essential oils from (Tunisian) Artemisia campestris and Artemisia herba-alba. J. Essent. Oil Res. 20, 471-477

Paris R.R., Moyse H., 1967. Matière Médicale. Tome 2. $2^{\text {nd }}$ Edition. Masson et Cie (Editors), Paris

Rosato A., Vitali C., De Laurentis N., Armenise D., Milillo M.A., 2007. Antibacterial effect of some essential oils administered alone or in combination with Norfloxacin. Phytomedicine 14, $727-732$
SAS, 1991. User's Guide. Statistical Analysis Systems. Version 6.10. SAS Institute Inc. Cary, NC

Scora R.W., 1973. Essential leaf oil variability in green, variegated and albino foliage of Myrtus communis. Phytochemistry 12, 153-155

Van Soest P.J., Robertson J.B., Lewis B.A., 1991. Methods for dietary fiber, neutral detergent fiber and non-starch polysaccharides in relation to animal nutrition. J. Dairy Sci. 74, 3583-3597

Zaouali Y., Boussaid M., 2008. Isozyme markers and volatiles in Tunisian Rosmarinus officinalis L. (Lamiaceae): a comparative analysis of population structure. Biochem. Syst. Ecol. 36, 11-21

Zrira S., Elamrani A., Benjilali B., 2003. Chemical composition of the essential oil of Pistacia lentiscus L. from Morocco - a seasonal variation. Flavour Fragr. J. 18, 475-480 